\title{
The influence of Salvador Dalí on Social Communication in the Years Following Second World War
}

\author{
Ticiana Dine \\ Ph.D Cnditate European University of Tirana, Albania, Faculty: Social Sciences, Profile of Sciences of Communication \\ Email" ticianadine@gmail.com
}

\section{Doi:10.5901/ajis.2015.v4n2s2p125}

\begin{abstract}
The study will be referred to a world renowned surrealist artist who gave his contribution in all directions. Salvador Dali was known not just in art history as an artist but also as a genius figure that went deeply into psychology, philosophy, symbolism, mysticism and science and furthermore proposed a whole new form of interpreting and observing the work of art through selfinduction Paranoid-Critical Method proposed by himself. Some of the theories proposed by Dali are inspiring many scholars still today.
\end{abstract}

Keywords: Surrealism, social perception, Dalí, Nuclear Mysticism, Second World War

\section{Introduction}

Although Surrealism was sprung up after First World War it continued to be followed afterwards affecting not only the visual arts but also the theatrical scenes, theaters and all forms of the conception of reality. Second World War brought disorientation and change not only in the social cultural and political terms but mainly in art. After a few years, around 1950 we can see the emergence of socialist realism that was adopted very quickly and was seen as the most appropriate style to describe social conditions as well it was easier to understand by the masses even though still very surrealist artists introduced many elements emphasizing that as socialist realism and surrealism inserted many elements in their works to express criticism in contemporary society. Surrealism was based on psychic automatism, a concept wherein the unconscious of artist dictated the creation of images without the influence of consciousness in the surreal works. The images of irrational, dreams and qualities, which usually were involved without the knowledge of the observer for personal psyche of the artist often confounded the interpretation, without mentioning the social criticism, which was applied in social realism and for problems evolved by social realism because the psychic automatism was not understood by social Surrealists as far as Abstract Expressionism surrealist artists, who raised a creative process thanks to it the images were created by psychic automatism process as well as freedom of the unconscious within the artist had beaver away. If social Surrealists based their work onto the real life and affected the physical world, Surrealists in turn were based more on symbols and dreams and to self-induction Paranoid process that was written and applied by Salvador Dalí himself. Social conditions in the years 1900 were talking about a chaotic world which brought economic difficulties and spiritual confusion to masses in Europe and in America as well by placing the artist all but into disqualified plan...

\section{Research Methodology}

1. How influenced Dalí on society and was understood by society itself?

2. How Dalí became part of the society after the war together with "war trauma"?

3. What were the ensemble's symbols that Dalí got into it during the first atomic bomb on Japan?

The methodology of the research was based on written literature, two manifestos of Andre Breton on surrealism, studies and newspapers that talk about the years after the First World War and surrealist movement which had begun by artists at the time. Two manifestos of Andre Breton were as a propellant on attitude and artistic research in a chaotic period and the impulse of these artists group and mainly on visual art of Salvador Dalí. 


\section{Hypothesis}

Dalí would describe the political situation through mysticism and symbolism that affected the mental and spiritual aspects of the masses at the time through what he called Nuclear Mysticism period.

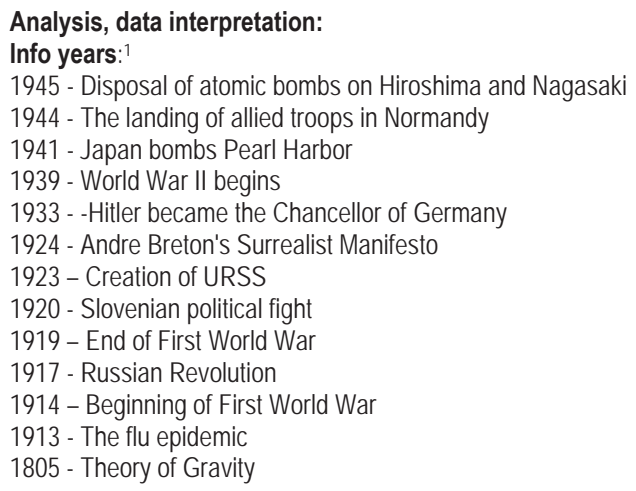

Besides the works of art will be reviewed even the years which influenced on surrealist artists but mainly on Dalí as well. Carefully will see some of his works in the way he reflected the reality, chaos and major depression. In the 1945 after the atomic bomb Dali will make a difference because he will change his points of view paintings objects or human in an atomic nuclear form, calling this period of his creativity Nuclear Mysticism. The war trauma was not show by Dali in the same way as did Picasso or Goya but it is shown in an mystic symbolism were people and fear mix together to avoid the reality, as a result they are confused, depressed and become paranoid. The paranoid for Dali was not as Freud see it but as the avoidance of reality (how did the humans in that period seeing the reality in another way). The self -paranoid induction is not so complicated as it will seem but what war and chaotic society provide or cause to human people. This is what make the difference between Dali and other artist in that period. The other artist will focus on literature, philosophy rather than mysticism, the war and its chaotic mind influence or paranoid human sense. In 1935 he describe himself as a fish swimming between "the cold water of art and the warm water of science" 2

\section{Beginning of surrealism}

Surrealism is a cultural movement that affected the visual arts, literature, the watch and interpretation on the work, it touched the scenes of theater, film, ballet and others, besides that this cultural movement dates back to about 1920 and seeks to solve human spiritual contradictions presented in a dream as well the difference between the dream and the reality, social conditions and the presence of the artist, art and social political chaos. These artists painted and touched scenes which may be perceived not only from an illogical point of view, furthermore they painted supernatural creatures, the presence of elements and figures beyond the reality expecting so an interpretation beyond the logic. The artists of DADA movement after the First World War protested in meetings and performances within the art, by writings and works of art by rejecting the aesthetic and artistic principles established by then.

Besides the theories of Andre Breton 's automatic writing, the artists such as Max Ernst, Man Ray, Paul Eluard, Andre Masson, Giorgio de Chirico, Joan Miro, Yves Tanguy, Marcel Duchamp, Salvador Dali, etc. bound their works with subliminal dreams, with the methods of development of freedom of imagination, often linking it to a state of insanity, and would be exactly Salvador Dali the one who will overcome all the philosophy and the attitude of DADA and surrealist artists stating that "There is only one difference between a madman and me that I am not mad". According to the poet Pierre Reverdy as much will be the connection of two contrasting realities the stronger will be the image, the greater will be the power of emotion and poetic reality. Surrealists sought to revolutionize the human experience in personal cultural and political terms, they demanded to free people from reality and false structures. According to Breton the main goal of

\footnotetext{
1 http://es.slideshare.net/busumi/dali-la-persistencia-de-la-memoria

${ }^{2}$ Dali and Science- Discover More
} 
surrealism was durability of social revolution, which in different surrealist time was committed to communism and anarchy. Surrealism intended to go outside the moral rules and ethical concern, outside the reason and self-control. Although the Surrealism started after the First World War it continued to be followed afterwards influencing not only on the visual arts but also on theatrical scenes, theaters and all forms of the conception of reality. Second World War brought a disorientation and change not only in social cultural and political terms, but mainly in the arts. After a few years around 1950 we can see the emergence of socialist realism that was adopted very quickly and was seen as the most appropriate style to describe social conditions, in addition it was easier to understand by the masses though still very surreal artists and introduced many elements as socialist realism and surrealism as they introduced elements in their works to express criticism in contemporary society. Surrealism was based on psychic automatism, a concept wherein the unconscious of artist dictated the creation of images without the influence of consciousness in the surreal works. The images of irrational, dreams and qualities, which usually were involved without the knowledge of the observer for personal psyche of the artist often confounded the interpretation, without mentioning the social criticism, which was applied in social realism and for problems evolved by social realism because the psychic automatism was not understood by social Surrealists as far as Abstract Expressionism surrealist artists, who raised a creative process thanks to it the images were created by psychic automatism process as well as freedom of the unconscious within the artist had beaver away. If social Surrealists based their work onto the real life and affected on the physical world, Surrealists in turn were based more on symbols and dreams and to self-induction Paranoid process that was written and applied by Salvador Dalí himself. Social conditions in the years 1900 were talking about a chaotic world which brought economic difficulties and spiritual confusion to masses in Europe and in America as well by placing the artist all but into disqualified plan. Precisely in this period many artists as Marcel Duchamp, René Magritte through their works quite differently from what was previously seen in the works of art would address their aesthetic, artistic and philosophical watch to the politics also as an ideological critique wherein the politics was presenting an instability and a visual frustration showing in that way a chaotic, mental and spiritual world where was not only the artist but the masses as well. This was the way that the Surrealists used to introduce their works which at first glance resemble a dream by confounding the viewer but realistically they represent the viewer. We must remember that in this period Sigmund Freud who dealt with largest issues of that time which was psychoanalysis in a time where most suffer from depression, hallucinations and self-identification and were precisely his theories that challenged those of Andre Breton and opened a new path for an artist as Dalí who would not abandon the mystical, psychological and symbolic world until the end of his life. The years 1900 as well as the Second World War brought a major depression and difficulties to survive. The survival that was the dominant demand in every sphere of American life, and not only of that, became politically burdensome, so how could these artists and especially Dalí keep up the social criticism, spiritual and mental confusion of masses while the society was in political and social chaos and was struggling for survival.

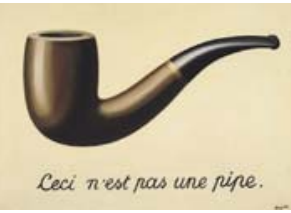

Rene Magritte's work This Is Not a Pipe, where in fact, the artist presents a drawing in which he painted a tobacco - pipe. Into this work in artistic terms we can see the linguistic play in which the artist says if this is a smoking pipe then "try to light it". The second linguistic aspect is that the word pipe varies in philosophical and symbolic terms because it presents something that people can change it, can light it because is it two dimensional.

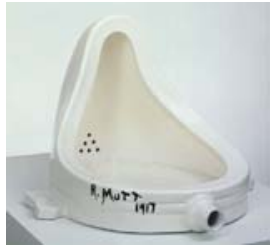

In political terms the pipe itself can present society which was unable to change the political movements at the time. In artistic terms is played by the image and the title of the work, in social terms the interpretation can be aesthetic or 
anesthetic where some may see an ornamental image and the other part feels the need to truly enjoy a puff of it (a smoker).

Marcel Duchamp with one of series of readymade artworks called "Fountain" again plays with philosophical and mystic terms where an object which we are used to see it with a functional appointee is introduced to us to see and interpret it in a very different context, exactly here we can see the game that these artists of surrealist and Dadaists movement are teaching the masses to adapt to a reality quite different from what they were accustomed to and to use certain items and to see them as objects aesthetically acceptable, so the anesthetic turned to aesthetics. But up to this point we have artists who play with the language or the context of the object of reality learned by senses and logic where something is but it is not like we are used to perceive or understand. Is played with aesthetics, are demolished the artistic principles and are starting the brand new form of "redesigning" or "reconstruction" of art. The artists of Dadaists movement and also the Surrealists later would follow such philosophy that will continue to play with philosophical context in art. He who will not deal with these visual forms but will get through the human psyche and will propose completely new theory that would exceed theories written thereat by Andre Breton and would insist that he was more surrealist then the so-called Surrealists would be Salvador Dali. On the eve of Second World War both Gala and Dalí were transferred to America. After the atomic bomb disposal Dalí had an attraction to the power of the atom and to the physical dynamics.

He incorporated some physical knowledge into his artworks calling this style Nuclear Mysticism. ${ }^{3}$ In one of his interviews Dalí claims that "nothing is more sexual than collision and explosion of nuclear inter- atomic conflicts." He also speaks in an interview on nuclear mysticism. Dalí said that at different stages of his life was focused on radical studies that were contemporary then. Below we will present some works which show that Dalí is partly disconnected from oneiric (of or relating to dreams or dreaming) of Sigmund Freud thinking through closely the problems that were bothering many European countries. The artwork (fig1) below appears mostly in dark colors which indicate a condition which does not coincide with a dream or with a momentum but with a grim condition into which is included a period of wars, bombings and loss of people. In the portrait in front, instead of eyes, nose and lips is placed a plane which shows moreover the bombing, portrait on the left shows the suffering, realistic portrait, wrinkled and open mouth demonstrates again a condition that was not at all oneiric or mystical but a reality (some claim that this portrait demonstrates the fear of Dalí himself, although the portrait doesn't have any similarity with Dalí himself) between human creature and destruction of the atomic bomb. We can see the egg and circles as well which show the atomic globules which were chain to achieve the goal of bombing.

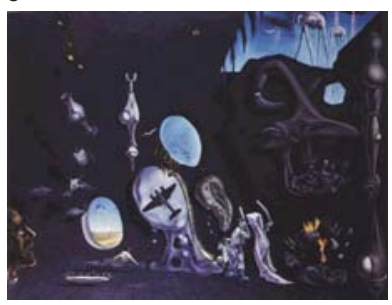

Fig.1 Atomica Melancholica

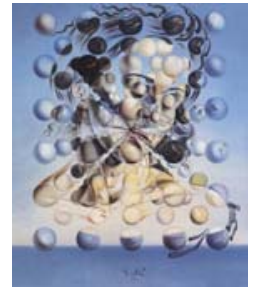

Fig.2 Galatea of the Spheres

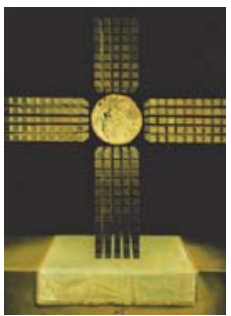

Fig.3 Nuclear Cross

The second artwork (Fig.2) demonstrates again the connection of Dalí with feats that brought the atomic bomb; the perspective is also a key part of the work. For Dalí the atomic bomb was the beginning of a new era, not only in terms of what it brought, but also in the form of entirely new conception according to Dalí, where his works will already be filled with images of figures that testify fear and his relations with science. The third artwork (Picture 3) again proves the bound of Dalí with science and physics by painting a cross which would be strongly rejected if was presented to church or if it belongs to the Renaissance period. Dalí interlaced the mystique with religiosity and science in this work and always for not dividing the meticulous drawing, claiming for a mystical as well scientific interpretation. Dalí rightly emphasizes ${ }^{4}$ how people already knew how to make an atomic bomb, but, "no one knows of what is made the Mystic fluid, the medium of painting in which the brothers Van Eyck or Vermeer van Delft dipped their paintbrushes". Dalí in Mystic Manifesto describes the change that was happening to him then: "Nothing more devastating can happen to an ex-surrealist in 1951 than initially to be mystic and secondly to be able to draw. I am experiencing both these forces simultaneously..." He

\footnotetext{
${ }^{3}$ http://greensurrealism.pbworks.com/w/page/15877249/Salvador\%20Dali

${ }^{4}$ Dali by Robert Descharnes and Gillet Neret (page. 158)
} 
goes on in saying that: "The explosion of the atomic bomb on August 6, 1945 conveyed inside of me a seismic shock. Since then the atom has become the center of my thought. A lot of works which I painted in this period are expressing the endless fear that embraced me when I heard about the bomb explosion. I used my critical approach to analyze the world. I want to perceive and understand the hidden powers of the laws of things, in order to have them in my hands..."
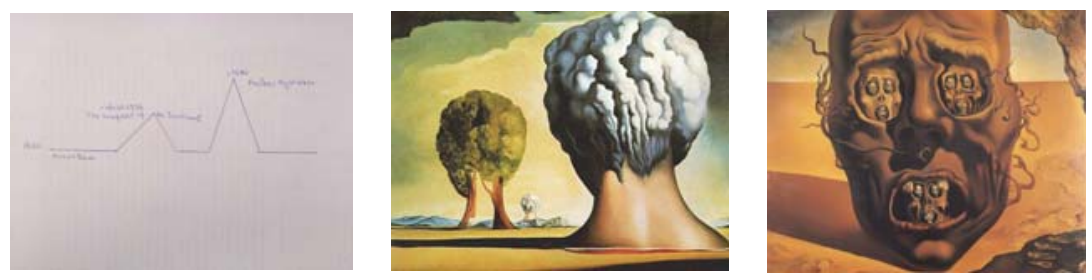

In the overhead artwork we can see again the fear of Dalí about the destruction which was brought by atomic bomb. Into this artwork there are presented three objects, the object closer represents the head of a woman that is connected to the object at the end, where the hair shapes not the appearance of the gray hair rather than the form which is created by atomic explosion, dense clouds and white color are combined with the dark gray. In the background or in perspective, we see a tree, again in the form of a head which looks like a green tree in nature. What we can see clearly in this work is the very nature and atomic explosion.

If we look at works by analytical eye we can see that fear doesn't appear in the way that Dalí himself asserted about the atomic explosion, rather than a condition that can be seen, studied and painted as it can do a researcher and not a man who is afraid of death. I do not think that Dalí was afraid of death even so I think that the embodiment of science, mystics, symbolic, little bit of oneiric and artistic has been as organic in a way that doesn't leave any option to consider it as a form all but tragic.

If we compare it with the Picasso's works La Guernica where was exposed the war, we can see that Picasso presents tragedy, dying, suffering and oppressed people, the horses that are falling, neighing and bringing out the teeth treading on the human bodies. Here we can really see the fear or experience of the artist but, in the works of Dalí we can see a more rational and cool watch than involved emotionally or scared. The second work as its title "Fear of Death" doesn't represent anything more but being too philosophical where the skulls are seizing the skull and portraying the fear.

\section{Conclusions}

Dalí was reposed on symbolic and oneiric aspect, because the dreams itself according to Freud are the impulses that come from everyday life and get such forms and combinations that confound the dream and its interpretation. Consequently, Dalí would not stopped to represent these external impulses which harass the human psyche and reflect not just the individual but also the circumstances and external social impulses at the time (which cannot be excluded from the human unconscious, they make up the shape of our attitude.) For this we cannot say that Dalí is an artist as Kandinsky who connects the music with lines and colors into the picture or a philosophical performer as was Rene Magritte. Dalí got into mystique, philosophic, symbolic and oneiric but Dalí as well got into the reality in which was living at the time the human being. To the question if was understood Dalí by his contemporaries I would answer that the concern of Dalí was not to be understood by his contemporaries than to do the role of a scholar and of a genius creator that reflects the reality of his time and tries to document and bring something to successors than just to mirror the emotional situation or a reality without artistic, symbolic and mystical interpretation. For this when Dalí was been asked in an interview which has been the contribution given by Dalí to the art, he said that has not given anything to art, as long as he considered himself a bad painter because he was much more intelligent as to be a good painter.

\section{References}

American Social Surrealism http://www.jstor.org/discover/10.2307/1557395?sid=21105715790921\&uid=3737464\&uid=4\&uid=2

http://es.slideshare.net/busumi/dali-la-persistencia-de-la-memoria

http://greensurrealism.pbworks.com/w/page/15877249/Salvador\%20Dali

Dali by Robert Descharnes and Gillet Neret (page. 158)

Dali and Science- Discover More (National Gallery of Victoria Education Resource) 